\title{
THE MICROSTRUCTURE OF MULTILANGUAGE DICTIONARIES: INFORMATIVENESS OF COMPONENTS
}

\author{
Gulnaz I. Mardanova ${ }^{1}$ \\ Rezeda N. Karimullina ${ }^{2}$ \\ Guzel N. Karimullina ${ }^{3}$ \\ Tatyana E. Karpenko ${ }^{4}$
}

Abstract: There is a need to systematize the information represented by dictionaries in modern bilingual linguography. The microstructure of bilingual (Russian-Tatar, Tatar-Russian) dictionaries is analyzed in the article. The object of the study was more than 200 language reference books (19512015) published in Russia.The following system of concepts is considered as a dictionary microstructure: a dictionary entry, a header unit, a phonetic characteristic, a grammatical characteristic, a head unit semantization (interpretation, translation equivalent), compatibility, etymological information, lexicographic illustration and lexicographical litter. Traditional forms of a head unit are described in the course of the analysis, the cases of an initial form unequal submission are revealed, etc. Besides, phonetic characteristics, etymological data presentation methods are analyzed in modern bilingual language reference books. During the analysis of the Tatar dictionary microstructure, it was found that not all vocabularies contain all of the listed zones, an initial form of a header unit is not fed in the same way, several words can be used as a head unit, most of the dictionaries $(56 \%$ of the total number) has no examples of use, dictionary marks (grammatical, terminological, etc.) within the same dictionary; they are presented inconsistently.

A comprehensive study of dictionary microstructure demonstrates the existence of various kinds of discrepancies and inaccuracies, which

\footnotetext{
${ }^{1}$ Kazan Federal University, Institute of Philology and Intercultural Communication.

2 Kazan Federal University, Institute of Philology and Intercultural Communication, re_ka@mail.ru, 89053770541.

${ }^{3}$ Kazan Federal University, Institute of Philology and Intercultural Communication.

${ }^{4}$ Ablai khan University of international relations and world languages, Kazakhstan, Almaty city.
} 
are associated mainly with the violation of one of the leading principles of linguography - the principle of uniformity.

Keywords: microstructure, multilingual dictionary, dictionary entry, linguography, Russian language, Tatar language.

\section{Introduction}

The rapid development of linguography (lexicography), including bilingual one, involves not only the creation of new dictionaries of various types, but also the systematization, the generalization of information provided by reference books, which is noted in many modern studies [1, 2, 3, 4], etc.

Within the framework of this study, the microstructure of bilingual language reference books of the second half of the 20th and the beginning of the 21 st century is analyzed. A dictionary microstructure considers the following system of concepts: a dictionary entry, a heading unit, a phonetic characteristic, a grammatical characteristic, the semantization of a head unit (interpretation, translation equivalent), compatibility, etymological reference, lexicographic illustration, lexicographical litter $[5,6]$. The results of the research show, that a significant part of the shortcomings is related to the violation of one of the leading principles of linguography - "the same should be presented and described in a dictionary in the same way".

\section{Methods}

The methods of linguistic description and comparative method are used in the work.

\section{Results}

The basic unit of a dictionary entry is a heading unit. A heading unit is a language unit (a word, a morpheme, a phraseological unit, etc.), which leads a dictionary article and acts as an object of a dictionary description. A head unit is usually given in an original form (nouns and adjectives - in the form of singular, nominative case, male gender, verbs - in the form of an infinitive, etc.).

During the analysis of bilingual (Russian-Tatar) dictionaries, the cases of bringing the Tatar equivalent to the head units were revealed. As a rule, it is given for words, the Russian and Tatar spelling of which differs: айран - дйрән, джиен - жсыен, каляпуш - кәләпүш, мектеб - 
мәктәn, etc. «Tatar encyclopaedic dictionary» (1999). However, a number of words has no such an equivalent: джаннат (жәннәт), джумга (жомга), катук сыбызгы (кәтүк сыбызгы), etc.

In our opinion, it is advisable to produce the Tatar variant of the word informatively for all units, except for the cases when Russian and Tatar spellings do not differ.

It is doubtful to include deployed structures as deployed units, for example, in "Russian-Tatar Music Dictionary" (2007) for any language guide: on all strings, i.e. not to press the left pedal when playing the piano; smooth motion (considering that the article entry for the movement is given); Putting one hand under the other when playing the piano, etc.

Phonetic characteristic indication of a word pronunciation is given by the means of transcription, the letters of Cyrillic or Latin alphabets, etc.

According to some researchers, in particular, V.P. Berkov, a dictionary reflecting the materials of languages whose spelling differs, should include additional information, which is especially important for educational dictionaries [7].
Thus, within the bilingual dictionaries for learners, Russian language should include the transcription for the units with the features in pronunciation, for example, the combinations of -чн- [шн] подсвечник, скворечник еtс., -чт[-шт-] - чтоо, чтобы (ср. почта) etc. The analyzed handbooks, the input language of which is English, have no transcription, which significantly reduces their informative level; see, for example, "The English-Russian-Tatar Dictionary of Physical Terms" (1996), "The English-Tatar Dictionary" (2007), etc.

In the course of the analysis, it was found that only $33 \%$ of dictionaries where the input language is Russian, have an accent on all units of the input language, there is no such information in the remaining Russian-Tatar dictionaries.

The area of grammatical information includes the information about the basic morphological and syntactic properties of a heading unit. Morphological properties help to determine the part of speech of a dictionary unit, the verbs have a specific pair, and so on. Syntactic information in 
most dictionaries is of an episodic nature. Mainly it includes the provision of case management issues, etc.

The analyzed linguographic sources include:

A) simple grammatical characteristics in the form of litters, denoting the belonging of a unit to one or another part of speech; for example, и. исем (noun), ф. - фигыль (verb), сф. сыйфат (adjective), etc.

B) complex grammatical forms in the form of litters that assign a lexicographic unit to a particular subclass and thus to a certain class; for example, the nouns of Russian language have the indication of a genus, a verb has a form, transitivity / intransitivity.

\section{Complete grammatical}

information about a word is given rarely, as a rule, only in educational dictionaries. For example, in the "School Russian-Tatar Dictionary" (1989) the entire paradigm for words with suppletive bases is placed: я, меня, мне, мной, обо мне; in the "Russian-Tatar dictionary of word combinations" (1998) some nouns contain all endings of the case forms (singular and plural): автомобиль, -я, -ю, -ь, -ем, -е; -и, -ей, ям, -и, -ями, -ях; verbs have the forms of conjugation: адресовать (адресу| ю, -ешь, -ет; -ем, -ете, -ют; прош. адресовал, -а, -о, -и; повел. адресуй, те).

One of the important issues in Russian-Tatar linguography is the registration of Russian verb type pairs. Traditionally, a perfect form is taken for the initial (dictionary) form of a verb. This is the way in which the verbs are expressed in many Russian-Tatar dictionaries. Unfortunately, there are the cases when the uniformity in the provision of type pairs is not observed within a single dictionary; for example, in a biskapal (bi-directional) dictionary the verbs благодарить (perf. поблагодарить), вымыться (perf. мыться), дарить (perf. подарить), извиняться (perf. извиниться), etc. demonstrate the pair of type in parentheses; the verbs мириться, плакать, etc. have no such a pair of type in parentheses.

The syntactic characteristics include the information on the compatibility of a head unit with the grammatical forms of other words or with auxiliary words, which is transmitted using case-based questions; for example, любоваться <..> 
someone $<$... $>$, состязание $<\ldots>\sim$ ться (with someone) <...>. In Tatar-Russian dictionaries the syntactic characteristic is extremely rare, more often on the right part; see, for example, биз $Y<\ldots>2$. To become bored of someone, etc.

One of the most important areas of the dictionary is the zone of semantization of the head unit. Semantization includes the elimination of the uncertainty regarding the meaning of the word ", as well as the result of this elimination $[5,8]$.

One of the most important zones of the dictionary is the zone of a gead unit semantization. Semantization involves the elimination of uncertainty about the meaning of a word", as well as the result of this elimination $[5,8]$.

Semantisation in a bilingual and multilingual dictionary is most often carried out using foreign-language equivalents (translations): воздух ‘һава'; дыня ‘кавын'; звезда ‘йолдыз’; море 'диңгез'; аннотирование 'аннотацияләү'; издатель 'нашир'; фондохранилище 'фондосаклагыч', etc.

Often the headers of the dictionaries under study (usually internationalisms, terms, etc.) are translated equally, for example, акселерат <...> 'акселерат'; актёр > ..> 'актёр' in "Russian-Tatar Dictionary" (2009); бормашина < ..> 'бормашина' and вокализм <..> 'вокализм' in "Tatar-Russian dictionary" (2007), etc. Some units are given an interpretation (an explanation) in parentheses, for example: кондуктор <...> '1. кондуктор (работник железнодорожного, также городского транспорта) <...>'; кондор <...> 'кондор (хищная птища)' etc.

Unfortunately, a number of dictionaries does not provide an explanation for similar units, which, in its turn, reduces the information content of the reference book. For example, the "Educational Tatar-Russian Dictionary" (1993), intended for Tatar-speaking students, has no interpretation for the following words: гангрена, диверсант, интервенциия, мобилизация, фетр еtc. At that, an explanation is given for some units; for example, дизель (тип двигателя внутреннего сгорания), лекало (фигурная линейка), фирма (предприятие) etc.

One of the problems of translation linguography is the division 
of a described unit into values. Each word, as is known, has its own semantic structure in each specific language. In bilingual linguography, there are two points of view on the significance of a linguographic unit. First, the division of a word into the meaning of an output language does not depend on an input language, i.e. a unit in a bilingual dictionary should be divided into values in accordance with its semantic structure. Secondly, the delimitation of unit values of an input language is determined by the number of translating equivalents [7]. It should be noted that there are no objective methods for a word meaning delineating. As a rule, compilers take the division into values in an explanatory dictionary as their basis, sometimes combining values or breaking up some values into two and several ones.
As a rule, different values of a head unit are marked by a) Arabic numerals:

ледяной $<\ldots>1$. боз; < ..> 2. бозлы; < ..> 3. боздай, боз кебек; < ..> 4. <..> салкын, жан өшеткеч <..> "School Russian-Tatar dictionary" (1989) or b) separated by a semicolon:

авыр <..> 'тяжелый; трудный <..>'; хисап <..> 'счет; расчет; учет; отчет <...' «TatarRussian, Russian-Tatar dictionary» (2001).

The difficulty concerning the isolation values often leads to the differences in the semantic characteristic of lexical units: in some sources a word is given as unambiguous, in others it is as multi-valued one.

Compare:

\begin{tabular}{|c|c|c|}
\hline $\begin{array}{l}\text { The Tatar-Russian Dictionary of } \\
\text { Education (1993) }\end{array}$ & $\begin{array}{l}\text { The Tatar-Russian } \\
\text { Study Dictionary (2008) }\end{array}$ & $\begin{array}{l}\text { The Tatar-Russian } \\
\text { Dictionary: in } 2 \\
\text { volumes (2007) }\end{array}$ \\
\hline $\begin{array}{l}\text { абага } \\
\text { ‘папоротник } \| \text { папоротниковый } \\
\text { <...> }\end{array}$ & $\begin{array}{l}\text { абага } \\
\text { 'папоротник, } \\
\text { кочедыжник, орляк // } \\
\text { папоротниковый' }\end{array}$ & $\begin{array}{l}\text { абага }<\ldots> \\
\text { папоротник, щитовник } \\
<\ldots>\text {; } \\
<\ldots \text { кочедыжник } \\
<\text { с..> см. арляк }<\ldots>2 . \\
\text { абагалык } 3 .\end{array}$ \\
\hline
\end{tabular}




\begin{tabular}{|c|c|c|}
\hline & & $\begin{array}{l}<\ldots> \\
\text { папоротники'<..> }\end{array}$ \\
\hline $\begin{array}{l}\text { кайтаваз <...> '1) эхо < ..> 2) } \\
\text { перен. отклик' }\end{array}$ & $\begin{array}{l}\text { кайтаваз <..> 'эхо, } \\
\text { отклик' }\end{array}$ & $\begin{array}{l}\text { кайтаваз <...> 'эхо, } \\
\text { отклик; отзвук <...>' }\end{array}$ \\
\hline $\begin{array}{l}\text { башваткыч }<\ldots>1 . \\
\text { головоломка, шарада }<\ldots>2 . \\
<\ldots>\text { головоломный }<\ldots>\end{array}$ & $\begin{array}{l}\text { башваткыч }<\ldots> \\
\text { головоломка, шарада } \\
\text { // головоломный }\end{array}$ & $\begin{array}{l}\text { башваткыч }<\ldots> \\
\text { головоломка; ребус, } \\
\text { шарада и т.п. <..> } \\
<\ldots>\text { головоломный; } \\
\text { сложный, } \\
<\ldots>\end{array}$ \\
\hline
\end{tabular}

An important role in the disclosure of the lexical semantics of a unit is played by illustrations (pictures, drawings, photographs, etc.). The application of an illustration is practiced in bilingual linguography both in picture dictionaries and in branch (terminological) dictionaries.

In some analyzed illustrated dictionaries images are not presented to all units, and the reasons for their absence are often not clear.

In the zone intended to describe the compatibility of a unit, typical wordcombinations are given; for example, сущность <..> сущиость жизни $<\ldots>$; упаковать <..> упаковать книги etc. "Russian-Tatar Dictionary" (2009).
During the analysis of RussianTatar dictionaries, it was revealed that in a number of cases the way of giving a phrase in the same dictionary was not defined: by a separate dictionary entry or in the article of a reference word; see, for example,the "Brief Russian-Tatar Dictionary of Business Vocabulary" (2001):

\section{водительское}

удостоверение '<... >'

$$
\begin{aligned}
& \text { удостоверение ' }<\text {.. >' } \\
& \text {... личности '< ..>' } \\
& \text { регистрационное ... '<..>' } \\
& \text { служебное ... '< ..>' }
\end{aligned}
$$

The word-formation zone of a dictionary entry may contain:

1) a list of derivatives from the head units of words that form a 
dictionary socket; for example, in "Russian-Tatar Dictionary" (1997): морд|ва '<...>'; $>$ вин,

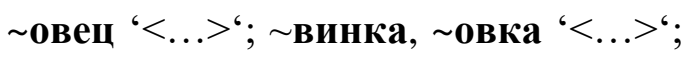
говский ' $<\ldots$. >' etc.

Some dictionaries contain diminutive forms, as well as the forms of the feminine gender for the names of professions, nationalities, etc.; see, for example, "School Russian-Tatar Dictionary" (1989): воротник < ..> (уменьш. воротничок) '<...'.

The analysis shows, that the indication of a heading unit wordbuilding capabilities greatly expands the information potential of a dictionary.

As a rule, the area of the etymological reference contains the information about a word origin and the information about a source language.

Within the same dictionary, you can find several options to describe the etymology of a borrowed word. So, for example, the "Tatar encyclopedic dictionary" (1999):

a) specifies only the source language: гисьянизм (Arab - rebellion, disobedience), унбаши (from the Turkic - the commander of ten warriors), саяхатнаме (Arabic-Pers., lit. - a book about a journey, etc. b) a prototype word is given: кадимизм (from the Arabic кадим - the old one), мектеб (Arabic - maktab, lit. a place where they write), йозбаши (Turkic йөзбашы - a centurion), минбаши (from Turk. меңбашы - the commander of thousand of soldiers, a captain), etc. At that, there are the cases when the same word-prototype in different articles is served by different ways; for example, азан (from the Arabian азина - to inform, to declare), муэдзин (from the Arabian азана - to inform, to declare, Turkic азанчы).

The zone of illustrative examples allows to specify and supplement the value of a header unit. The necessity of dictionary illustrations has been repeatedly shown and proved by many linguographers (see $[9,10]$, etc.).

Illustrative examples are given in many of the analyzed references. For some types of dictionaries, the absence of use examples is often a drawback. Thus, in the "Tatar-Russian, RussianTatar school dictionary: (for Russianspeaking students)" (2008), intended "for an active assimilation of the lexical minimum, <...> whose knowledge makes it possible to master Tatar 
language fluently", the lack of visual material makes it difficult to achieve a set goal by the authors.

A significant role in the description of a heading unit is made by dictionary marks. Unfortunately, it is not uncommon when litters to be placed inconsistently: зелпе бот. 'жимолость' и зирек 'ольха'; юнкер ист. 'юнкер' и большевик 'большевик' "TatarRussian Educational Dictionary" (1993); ноутбук информ. 'ноутбук' и компьютер 'компьютер', at that the litter hist. is gven erroneously for the word ржа "Russian-Tatar Dictionary" (2009), etc.

A number of dictionaries with regard to stylistic litter allows for some inaccuracies: in Russian-Tatar dictionaries, the mark colloq. is often understood rather broadly than in monolingual Russian dictionaries; for example, the word безмозглый 'мисез' in "Russian-Tatar Dictionary" (1997) is accompanied by the litter colloq., whereas in the "Large Explanatory Dictionary of Russian Language" (1998) this unit is equipped with the litter derogat.

Sometimes the authors provide the units, completely used in a neutral style by the litter "colloq" or "bookish": вздуться (разг.), располагать (книж.) "Russian-Tatar Dictionary" (1997).

Unfortunately, in some educational bilingual dictionaries, the litters such as obsolete, histor. are missing in a number of words, see, for example, the "Tatar-Russian Dictionary of Learning" (1993): большевик, хан (in "Tatar-Russian Dictionary" (2004), these units are given with the litter hist.).

\section{Discussion}

For a systematic and a complete presentation of the various types of information contained in a dictionary entry, you can bring a parametric analysis, the results of which allow you to identify language references that contain a particular parameter.

\section{Conclusion}

During the analysis of the Tatar dictionary microstructure, the following shortcomings were identified: a) an initial form of a heading unit represented in the dictionary differs from that described in the foreword to the dictionary, or served in a non-uniform manner; b) several words are indicated as a heading unit; at that the second word is 
not included with the reference in its alphabetical place, c) there is no accent in dictionaries, the input language of which is Russian $(33 \%$ of the total amount); d) most of the dictionaries (56\% of the total number) have no examples of use; e) an inconsistent use of dictionary litters (grammatical, terminological, chronological, etc.) within the same vocabulary e) all of the listed zones are not contained in each dictionary. For example, many types of analyzed dictionaries have no zones of phonetic information or etymological information, etc. The syntactic characteristic of a heading unit in Tatar dictionaries is extremely rare, more often on the right side of the Tatar-Russian dictionary.

Thus, the conducted analysis of bilingual dictionary microstructure contributes to a greater systematicity in the linguistic description, and also reveals a number of shortcomings: the incompleteness of information or the absence of dictionary entry areas, etc., the elimination of which will increase the information level of language references.

\section{Acknowledgements}

352

The work is performed according to the Russian Government Program of Competitive Growth of Kazan Federal University.

\section{References}

Ashrapova, A.H., Yusupova, A.S. Language and national identity in linguistic dictionaries (on material of bilingual dictionary of the Tatar language of the 19th century and the turn of the 20th century) // Journal of Language and Literature, Volume 6, Issue 1, 2015, pp. 318-321.

Dubichinsky V.V. Microstructure of the invariant dictionary. Dubichinsky V.V.// Bulletin of the Novosibirsk State Pedagogical University. - No. 4 (20). 2014.

https://cyberleninka.ru/article/v/mikrost ruktura-invariantnogo-slovarya

Gafiyatova E.V., M I. Solnishkina Multiword lexical entries in lsp dictionaries: Theoretical considerations // Journal of Language and Literature, Volume 6, Issue 2, 2015, Pages 71-75.

Nurmukhametova R.S., Zamaletdinov R.R., Sattarova M.R. The vocabulary of 
Tatar literary language (the first half of the XX century) // Life Science Journal, 2014, Volume 11, Issue 10, pp. 670-673.

Morkovkin V.V. About the basic lexicographic knowledge / V.V. Morkovkin // Textbooks and dictionaries in the system of Russian language as a foreign language teaching aids. - M.: Rus. lang. 1986a, pp. 102-117.

Dubichinsky V.V. Lexicography of Russian language: Textbook. / V.V. Dubichinsky. - Moscow: Flint: Science, 2009. - $432 \mathrm{p}$.

Berkov V.P. Bilingual lexicography: textbook / V.P. Berkov. - 2nd ed., revised and added. - M.: AST: Astrel, 2004. $236 \mathrm{p}$.

Parina I. Cross-Linguistic Equivalence of Idioms: Corpus vs Dictionary // Phraseology in Multilingual Society, pp. 363-376. Cambridge Scholars Publishing, Newcastle upon Tyne (2014)

Ayupova R.A. Illustrative Material in the Structure of Phraseographic Entries//Asian Social Science; Vol. 11, No. 7; 2015. pp. 284-289.
Yuldashev A.A. The principles of Turkic-Russian dictionaries compilation / A.A. Yuldashev. - Moscow: Nauka, 1972. - $416 \mathrm{p}$ 